\title{
Molecular identification of some fungi associated with soft dates (Phoenix dactylifera L.) in Saudi Arabia
}

\author{
Mashael Al-Mutarrafi ${ }^{1 *}$, Nagwa Thabet Elsharawy ${ }^{1,2}$, Aisha Al-Ayafi ${ }^{1}$, Ahmed Almatrafi ${ }^{3}$ and \\ Hayam Abdelkader ${ }^{1}$
}

\author{
${ }^{1}$ Microbiology Department, College of Sciences, University of Jeddah, Saudi Arabia. \\ ${ }^{2}$ Department of Food Hygiene, Faculty of Veterinary Medicine, New Valley, Assiut University, Egypt. \\ ${ }^{3}$ Department of Biology, College of Science, Taibah University, Almadinah Almunawarah, Saudi Arabia.
}

Accepted 25 November, 2019

\begin{abstract}
The Kingdom of Saudi Arabia is considered one of the major dates producing zones in the world, contributing $13 \%$ of the total world production. Most of the dates are delivered to local markets without any treatment thus, may be leading to microbial contamination which may increase the incidence of microbial growth. Some pathogenic fungi associated with soft dates (Phoenix dactylifera Linn.) collected from Almadinah Almunawarah, local markets, was isolated and molecularly identified during summer 2019. Contaminated date samples (Sukkary, Ajwa, Shalabi madinah, Barni and Sogea) were placed on PDA plates and incubated at $26^{\circ} \mathrm{C}$ for 5 days. Morphological and molecular identification of the resulting fungi were investigated. Molecular identification of fungal isolates was conducted using the internal transcribed spacer (ITS) region of the ribosomal DNA (rDNA). Fungal DNAs were amplified by PCR using ITS1-F (5'TCCGTAGGTGAACCTGCGG-3') and ITS4 (5'-TCCTCCGCTTATTGATATGC-3'). The purified PCR products were sequenced and the obtained nucleotide sequences were submitted to GenBank on the NCBI. The results showed that the most dominant isolated fungi were Aspergillus niger (100\%) associated with "Sogea", followed by Aspergillus tubingensis (66\%) isolated from "Shalabi Almadinah" (40\%), Rhizopus stolonifer (36.3\%) associated with "Ajwa", Talaromyces minioluteus (14.2\%) isolated from "Sukkary", respectively. Soft dates are most likely contaminated due to the artificial rise in moisture content and the related inappropriate storage conditions. In conclusion, the study has declared that Aspergillus spp. considered the most fungal contamination of date fruits. Fungal contamination may have an effect on the public health by their mycotoxins which may lead to severe poisoning, diarrhea, emesis, and death. Most date fruits sold and marketed are neither covered nor protected in any way from environmental contamination. If these dates are consumed without thoroughly washing that may induce imminent mycotic infection. The study recommended that prevention of dates fruit mold spoilage should be avoided by application of hazard analysis, critical control point programs and adherence to hygienic good manufacturing practices.
\end{abstract}

Keywords: Ajwa, Aspergillus niger, Aspergillus tubingensis, PCR, ITS sequencing, molecular identification.

${ }^{*}$ Corresponding author. E-mail: waaaw-2009@hotmail.com.

\section{INTRODUCTION}

Date fruit is considered one of the most common fruits in the Middle East, especially in the Arabian Peninsula. Dates are consumed fresh (Rutab) or after partial drying and storage (Tamar) during off-season (Al-Bulushi et al., 2017). The Kingdom of Saudi Arabia is considered one of the major dates producing zones in the world, contributing $13 \%$ of the total world production. Therefore, the Kingdom of Saudi Arabia exerts great effort to maximize dates production and maintain this market share through product quality and safety assurance 
(Gherbawy et al., 2012).

Date is marketed throughout the world as a high-value fruit crop and low-cost food. Production of dates increased from 4.60 million tons in 1994 to 6.9 million tons in 2004 worldwide (FAO, 2008). Mycotoxins, especially Aflatoxins (AFs) and OTA, may be found in date fruit (Abdel-Sater and Saber, 1999; Alghalibi and Shater, 2004; lamanaka et al., 2005). OTA contamination of 20 data samples sold in Brazil of global origin was investigated by lamanaka et al. (2005) only two samples found to have 0.1 to $5 \mu \mathrm{g} / \mathrm{kg}$ contaminations with OTA. The presence of Aflatoxin-B1 (AFB1), OTA and zearelenone has been reported in Egyptian dates analyzed by thin-layer chromatography (TLC) (AbdelSater and Saber, 1999). Two specimens were infected with AFB1 and OTA at levels of 300 to $390 \mu \mathrm{g} / \mathrm{kg}$, respectively, and 360 to $450 \mu \mathrm{g} / \mathrm{kg}$, with three date samples being contaminated with Zearelenone at 500 to $1000 \mu \mathrm{g} / \mathrm{kg}$. The criteria of General Standardization Organization (GSO) Policy (2010) for the Exposure Assessment of Contaminants and Toxins in Food and Food Groups should be consulted when the meaning of certain foods in total exposure to the contaminant is identified.

Date is marketed throughout the world as a high-value fruit crop and low-cost food (Mirza et al., 2019). They pass through five main stages of maturity as per Arabic tradition and internationally accepted terminology; Hababouk, Kimri, Khalal, Rutab, and Tamr (Al-Shahib and Marshall, 2003). The moisture content varies in the maturity stage of dates. The moisture content is relatively low in dried dates due to the drying process. Carbohydrates are the major source of energy in dates and average dates contain $54.9 \mathrm{~g} / 100 \mathrm{~g}$ of dry weight and dried dates contain $80.6 \mathrm{~g} / 100 \mathrm{~g}$. Protein and fats are present in small amount in dates (Elhindi et al., 2017).

Moreover, most of the dates are delivered to local markets and consumed by Saudi people without any treatment thus, may lead to microbial contamination which may increase the incidence of microbial growth due to high levels of sugars and nutrients element and their low $\mathrm{pH}$ values make them particularly desirable to fungal decayed (Singh and Sharma, 2007).

Recent studies found that fungal contamination, yeast and mold counts were higher than bacterial counts in both fresh and treated date (Shenasi et al., 2002). Therefore, fungi are considered the major causative agent of the spoilage of date fruits (Hasnaoui et al., 2010). Fungi are also responsible for off-flavor formation and production of allergenic compounds which lead to qualitative losses (Kader and Hussein, 2009).

However, dates are prone to contamination in the field during harvesting, transporting, storage, marketing and/or by the consumer. Fungi play a substantial role in spoilage of dates because of their pathogenicity to the harvested products. Fungi, that is, Aspergillus spp. and Rhizopus spp. may grow on high-moisture dates, especially when harvested following rain or high humidity periods (Al-Farsi and Lee, 2008).

Aspergillus sp. is found to be the most common fungi contaminating date fruits. However, microbial research on date fruits is limited in most of the date producing countries. The presence of Aspergillus niger damages date fruits and produces not only a loss of value but food safety concerns because of the potential of mycotoxins produced inside the fruit (Colman et al., 2012). There is a big shortage in research studies which examined the dates in Saudi Arabia and studying the different types of fungal spoilage affecting them. Therefore, the aim of current research is to detect the incidence (\%) of fungal infection in each type of tested date samples in Saudi Arabia under unfavorable storage conditions and to characterize those fungi using morphological and molecular techniques.

\section{MATERIALS AND METHODS}

\section{Sample collection}

Samples were collected from Al-Madinah Al-Munawarah markets in Saudi Arabia, based on their ripening stage which is related to the moisture and sugar content of the dates. About $50 \mathrm{~kg}$ of apparently infected date samples from five different date types (Ajwa, Barni, Sukkari, Shalabi Madina and Sogea) were collected from different markets in Al Madinah Al-Munawarah and were subjected for lab examination. About $150 \mathrm{~g}$ of dates packaged in polyvinyl chloride plastic films were transferred within several minutes after collection to an ice box container; aseptically handled and moved promptly to microbiology laboratory, College of science, University of Jeddah.

\section{Isolation and identification fungal isolates}

Infected dates were identified by physical examination according to the method of Jha (1995). Nevertheless, five samples from each variety were cut into pieces and a small piece $(1 \mathrm{~cm})$ of infected date fruit was surface sterilized by $2 \%$ sodium hypochlorite solution for 2 min, washed twice with sterile water and cultured on PDA plates then incubated at 26 to $28^{\circ} \mathrm{C}$ for 5 days. When colonies of different shape and colors was observed on the plates, single hyphen tips were cultured on PDA medium and incubated at 26 to $28^{\circ} \mathrm{C}$ for 5 days, sub-culturing each of the different colonies onto the SDA plates were done. Purified cultures were examined microscopically by staining with lactophenol dye. All fungal isolates were maintained in $4^{\circ} \mathrm{C}$ until used. Molecular identifications of isolated fungi were confirmed using ITS rDNA sequence analysis (Raja et al., 2017).

\section{Molecular identification}

\section{DNA isolation}

Fungal genomic DNAs were isolated using QIAamp DNA Mini Kit according to QIAGEN kit handbook. Fungal isolates were grown on PDA plates at $28^{\circ} \mathrm{C}$ for $72 \mathrm{~h}$. The plate surface was flood with $10 \mathrm{ml}$ fungal saline $(0.9 \% \mathrm{w} / \mathrm{v} \mathrm{NaCl})$, to harvest the conidia. $1 \mathrm{ml}$ saline suspension containing 1 to $5 \times 10^{6}$ conidia was measured photometrically at $A_{530}$. It is known that 1 to $5 \times 10^{6}$ cells yield about 20 to $30 \mu \mathrm{g}$ fungal genomic DNA. Fungal cells were centrifuged and 
$500 \mu$ lysis solutions (50 mM Tris, pH 7.5, $10 \mathrm{mM}$ EDTA, $28 \mathrm{mM}$ ßmercaptoethanol) was added to the collected cell pellet and incubated at $37^{\circ} \mathrm{C}$ for $30 \mathrm{~min}$. The tubes were centrifuged at full speed for $10 \mathrm{~min}$ and the supernatants were discarded. The pellets were resuspended in $180 \mu \mathrm{l}$ Buffer $\mathrm{AL}$ and $20 \mu \mathrm{l}$ Proteinase $\mathrm{K}$ and the tubes were incubated at $56^{\circ} \mathrm{C}$ for $10 \mathrm{~min}$. $200 \mu \mathrm{l}$ ethanol (96 to $100 \%$ ) was added to each sample, and mix well by vortexing. QIAamp Spin Column was placed in a $2 \mathrm{ml}$ collection tube and the mixture solution was carefully applied to the QIAamp Spin Column. The spin columns were closed and centrifuged at $6000 \mathrm{xg}$ for $1 \mathrm{~min}$. The filtrates in the QIAamp collection tubes were discarded. The QIAamp Spin Column was carefully opened and $500 \mu \mathrm{l}$ of Buffer AW1 was added and centrifuged at $6000 \mathrm{xg}$ for $1 \mathrm{~min}$. The QIAamp Spin Column was placed in a clean $2 \mathrm{ml}$ collection tube, and the filtrate was discarded. $500 \mu$ l of AW2 Buffer was added to QIAamp Spin Column and centrifuged at full speed for $3 \mathrm{~min}$. The QIAamp Spin Columns were placed in a clean $1.5 \mathrm{ml}$ microcentrifuge tube, and $150 \mu \mathrm{l}$ of AE Buffer was added to silica filter to elute the DNA. The Spin Columns were Incubated at room temperature for $1 \mathrm{~min}$ then centrifuged at $6000 \mathrm{xg}$ for $1 \mathrm{~min}$. Eluted in DNAs were kept at $-20^{\circ} \mathrm{C}$ until use.

\section{Quantification of nucleic acids}

The DNA was quantified spectrophotometrically by measuring the absorbance at $260 \mathrm{~nm}\left(A_{260} \mathrm{~nm}\right)$. The $A_{260}: A_{280}$ ratio of a nucleic acid extract was measured. Nucleic acid extracts were diluted 100 to $500 \mu$ with water before assay and the extinction coefficient for the DNA was calculated according to the following equation: $A_{260} \times 50 \times$ dil. factor $(\mu \mathrm{g} / \mathrm{ml})$. The integrity of the DNA was checked by agarose gel electrophoresis.

\section{PCR amplification}

Qiagen ${ }^{\circledR}$ Taq PCR Master Mix Kit was used to amplify fungal DNA samples via PCR and generate ITS rDNA gene product. A negative control of $2 \mu \mathrm{l} 0.1 \times \mathrm{TE}$ (TrisEDTA) was used. Fungal DNAs were diluted $1: 10$ to $0.5 \mathrm{ng} / \mu \mathrm{l}$ and $5 \mu \mathrm{l}$ of each DNA sample was added to $25 \mu \mathrm{l}$ of master mix containing $2 \mu \mathrm{l}$ of (25 pmole) ITS-F (5'CTTGGTCATTTAGAGGAAGTAA-3') and ITS4 (5'TCCTCCGCTTATTGATATGC-3') primer mix, $75 \mathrm{mM}$ of dNTPs, 1.5 $\mathrm{mM} \mathrm{MgCl}_{2}$ and 1.5U Taq DNA polymerase.

The thermocycler ( ${ }^{3}$ Prime Thermal Cycler, 3PRIMEX/02, Bibby Scientific Ltd) was used for amplification of the samples for a total of 35 cycles as follows: one cycle at $95^{\circ} \mathrm{C}$ for $3 \mathrm{~min}$, followed by 35 cycles at $95^{\circ} \mathrm{C}$ for $1 \mathrm{~min}, 50^{\circ} \mathrm{C}$ for $1 \mathrm{~min}$, and $72^{\circ} \mathrm{C}$ for $2 \mathrm{~min}$, followed by final extension cycle at $72^{\circ} \mathrm{C}$ for $10 \mathrm{~min}$, and a $10^{\circ} \mathrm{C}$ soak. An aliquot of $10 \mu \mathrm{l}$ of each PCR product was analyzed by electrophoresis on a $1 \%$ agarose gel containing $0.5 \mu \mathrm{g} / \mathrm{ml}$ ethidium bromide and visualized on UV transilluminator.

\section{Automated DNA sequencing}

The PCR products were purified by QIAquick PCR Purification Kit (QIAGEN) based on manufacturer's instructions. The purified products were sequenced using an automated DNA sequence (ABI PRISM 3700) using the Big Dye Deoxy Terminator cyclesequencing kit (Applied Biosystems) following the manufacturer's instructions. Sequences were submitted to GenBank on the NCBI website (http://www.ncbi.nlm.nih.gov). Sequences obtained in this study were compared with the GenBank database using the BLAST software on the NCBI website (http://www.ncbi.nlm.nih.gov /BLAST/). ITS Sequence and Phylogenetic Analysis DNA sequences were aligned using BLAST program. Phylogenetic trees were constructed after multiple sequence alignments using
Clustal W embedded in MEGA6 program and neighbor-joining method with 500 bootstrap replicates (Tamura et al., 2013).

\section{ITS sequence and phylogenetic analysis}

DNA sequences were aligned first with Clustal Omega, Multiple Sequence Alignment (EMBL, EBI). CLC Main Workbench V8.1.3 (Qiagen, Bioinformatics) was used to construct a neighbor-joining tree using Jukes-Cantor model (Jukes and Cantor, 1969).

\section{RESULTS}

Four spoilage fungi were isolated and identified from four types of soft dates morphologically and microscopically is shown in Figure 1. The isolated fungi were Aspergillus niger, Aspergillus tubingensis, Talaromyces minioluteus and Rhizopus stolonifer. Aspergillus niger are filamentous fungi, forming dark filaments (hyphae) and microscopically appeared as; a smooth and colorless conidiophores and spores with dark brown globose heads. While, Aspergillus tubingensis yellow-green dense colony clear radial lines, the back of colony is brown, with white mycelium and spherical spore. Talaromyces minioluteus is cylindrical with clear, vivid orange red to orange red stipe, and a greyish green capitulum with globose of smooth to slightly roughened conidia. Rhizopus stolonifer appeared as white, green and black colonized fungi.

The percentages of fungal contamination are illustrated in Figure 2 as following; Sukkary, Ajwa, Shalabi Madinah, Barni and Sogea soft dates were 39, 30, 20, 20 and 10\%, respectively.

The incidence of fungal isolates detected in each type of tested date samples were shown in Table 1 as follows; in Sukkary dates, Aspergillus niger was $39.7 \%$, Aspergillus tubingensis was 24\%, Talaromyces minioluteus was $14.2 \%$ and Rhizopus stolonifer was $22.1 \%$. However, the incidence of Aspergillus niger, Aspergillus tubingensis Talaromyces minioluteus and Rhizopus stolonifer isolates from Ajwa were; $0 \%, 54.5 \%$, $9.2 \%, 36.3 \%$ respectively. However, the incidence of Aspergillus niger, Aspergillus tubingensis detected from Shalabi Madinah were 34 and $66 \%$ respectively and free from Talaromyces minioluteus and Rhizopus stolonifer. In case of Barni, the contamination by $A$. niger and $A$. tubingensis was 37.5 and $62.5 \%$, respectively and free from other fungal spp. Sogea dates were contaminated only with $A$. niger (100\%).

The PCR product sizes of the ITS rDNA regions were of variable lengths, from 536 to $596 \mathrm{bp}$. A. niger isolate MJU-2 had the longest ITS rDNA region (596 and 600 bp), whereas Talaromyces minioluteus isolate MJU-6 had the shortest one (536 bp).

The DNA sequence and phylogenetic analysis presented in Figure 3 declared the sequence analysis of the ITS regions of the nuclear encoded rDNA showed significant alignments of 98 to $100 \%$ of accession number 


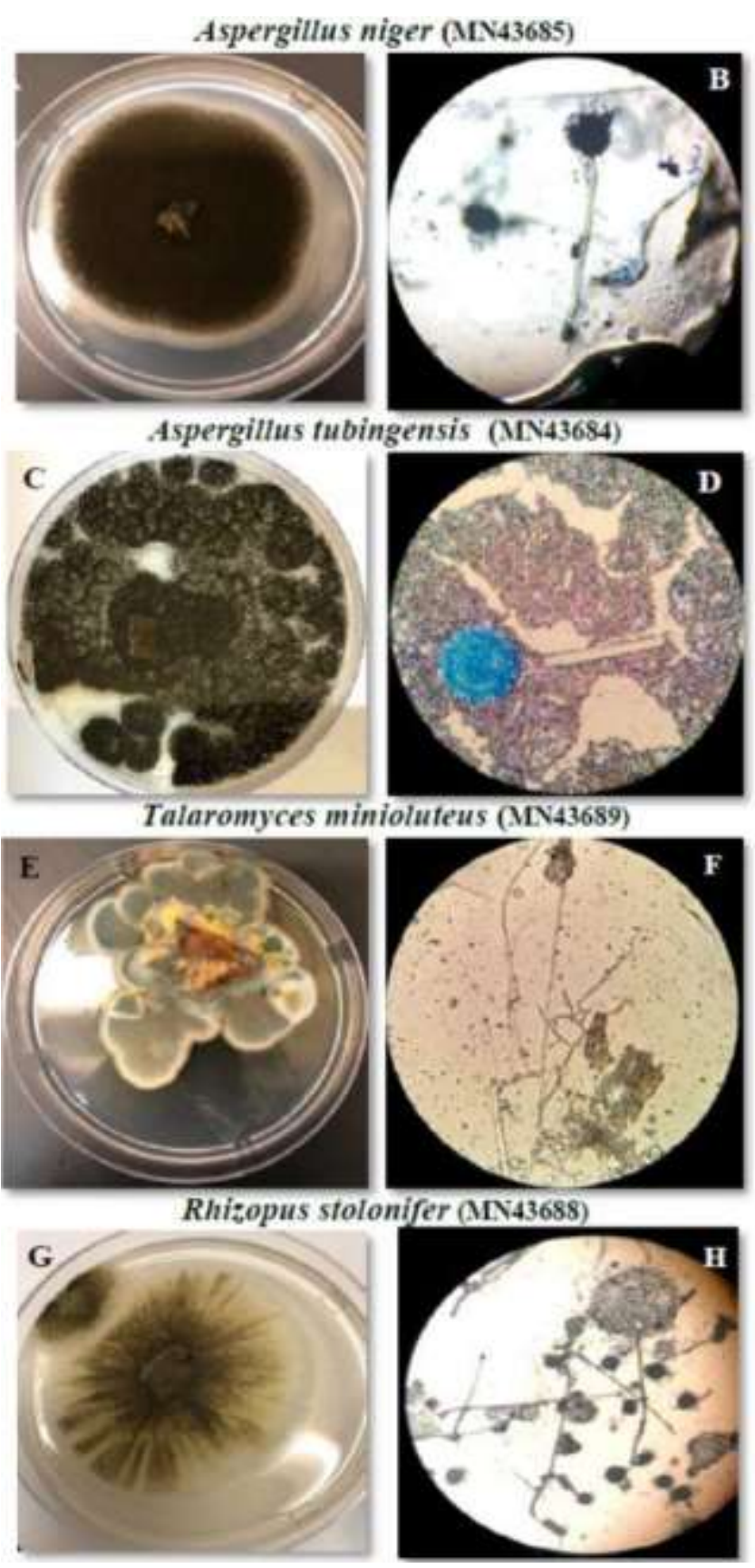

Figure 1. Morphological and microscopic examination of fungi isolated from contaminated soft dates. (A \& B) Aspergillus niger, (C \& D) Aspergillus tubingensis, ( $\mathrm{E} \& \mathrm{~F}$ ) Talaromyces minioluteus, ( $\mathrm{G} \& \mathrm{H}$ ) Rhizopus stolonifer.

MN413684 isolate MJU-1 for $A$. tubingensis with $579 / 580$ (99\%) identities. Alignment for accession number MN413685 for $A$. niger isolate MJU-2 with 589/596, (99\%) identities. Alignment for accession numbers MN413688 for Rhizopus stolonifer isolate MJU-5 with $584 / 590$ (99\%) identities. Alignment for accession number MN413689 for Talaromyces minioluteus isolate MJU-6 with 536/537 (99\%) identities. Similarities within

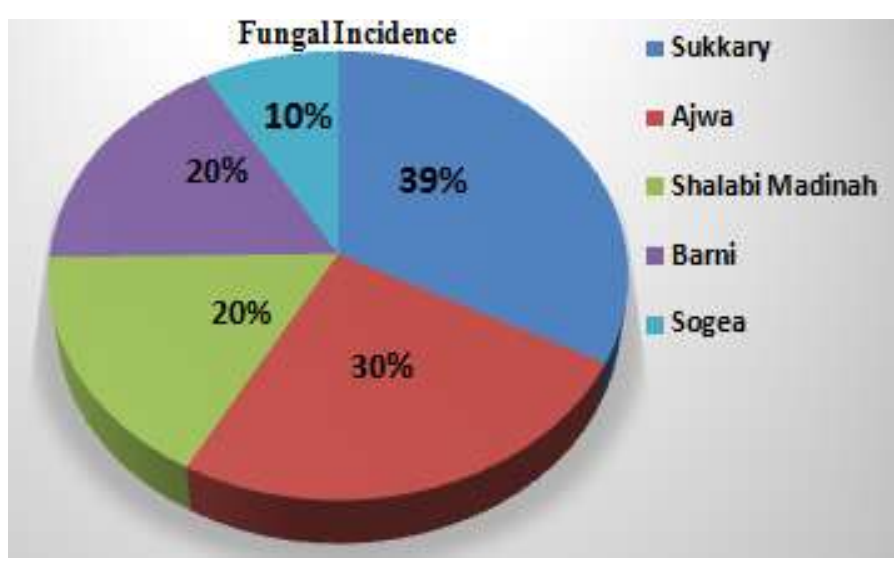

Figure 2. Percentages (\%) of spoiled soft dates types contaminated with post-harvest fungi collected from different markets at $\mathrm{Al}$ Madinah Almunawarah.

studied fungal accessions (MN413684 isolate MJU-1, MN413685 isolate MJU-2, MN413688 isolate MJU-5, MN413689 isolate MJU-6 were relatively high, within the range of 96 to $100 \%$. Figures 4, 5, 6 and 7, and Table 2 showed the dendogram generated based on the similarity percentages of the four fungal strains as well as reference strains obtained from Gen-Bank. Isolates within each species were clustered together and distinctly separated from the others. The generated dendogram shows that the studied isolates were clustered in three groups. The first group (I) includes MN413689 isolate MJU-6, the second group include the accession number MN413684 isolate MJU-1. The third group includes two accession numbers MN413685 isolate MJU-2 and MN413688 isolate MJU-5.

\section{DISCUSSION}

This study was carried out to identify fungi isolated from soft dates collected from Almadinah Almunawarah using morphological and molecular examination methods. Four fungal species were isolated and identified at the species level using rDNA ITS sequences comparison and analysis. The Isolated species belong to two classes as the following: Eurotiomycetes $(A$. niger, $A$. tubingensis and Talaromyces minioluteus) and Mucoromycotina ( $R$. stolonifer). The percentages of fungal contamination found in collected samples of soft dates; Sukkary, Ajwa, Shalabi Madinah, Barni and Sogea soft dates were 39, $30,20,20$ and $10 \%$, respectively.

Our results are in agreement with the results of another study conducted by Anjili et al. (2015) who reported about 1000 fruits of date palm obtained from four (4) markets from Yola Town Market which showed that the highest incidence fungal isolates from the samples were $A$. niger $(40.42 \%)$ and $R$. stolonifer $(22.45 \%)$. These have also been reported by Atia et al. (2009), Hashem (2009), 
Table 1. Incidence (\%) of fungal contamination among collected soft dates.

\begin{tabular}{lccccc}
\hline \multirow{2}{*}{ Fungal isolates } & \multicolumn{5}{c}{ Date types } \\
\cline { 2 - 6 } & Sukkary & Ajwa & Shalabi madinah & Barni & Sogea \\
\hline Aspergillus niger (MN43685) & $39.7 \%$ & - & $34 \%$ & $37.5 \%$ & $100 \%$ \\
Aspergillus tubingensis (MN43684) & $24.0 \%$ & $54.5 \%$ & $66 \%$ & $62.5 \%$ & - \\
Talaromyces minioluteus (MN43689) & $14.2 \%$ & $9.2 \%$ & - & - & - \\
Rhizopus stolonifer (MN43688) & $22.1 \%$ & $36.3 \%$ & - & - & - \\
\hline
\end{tabular}

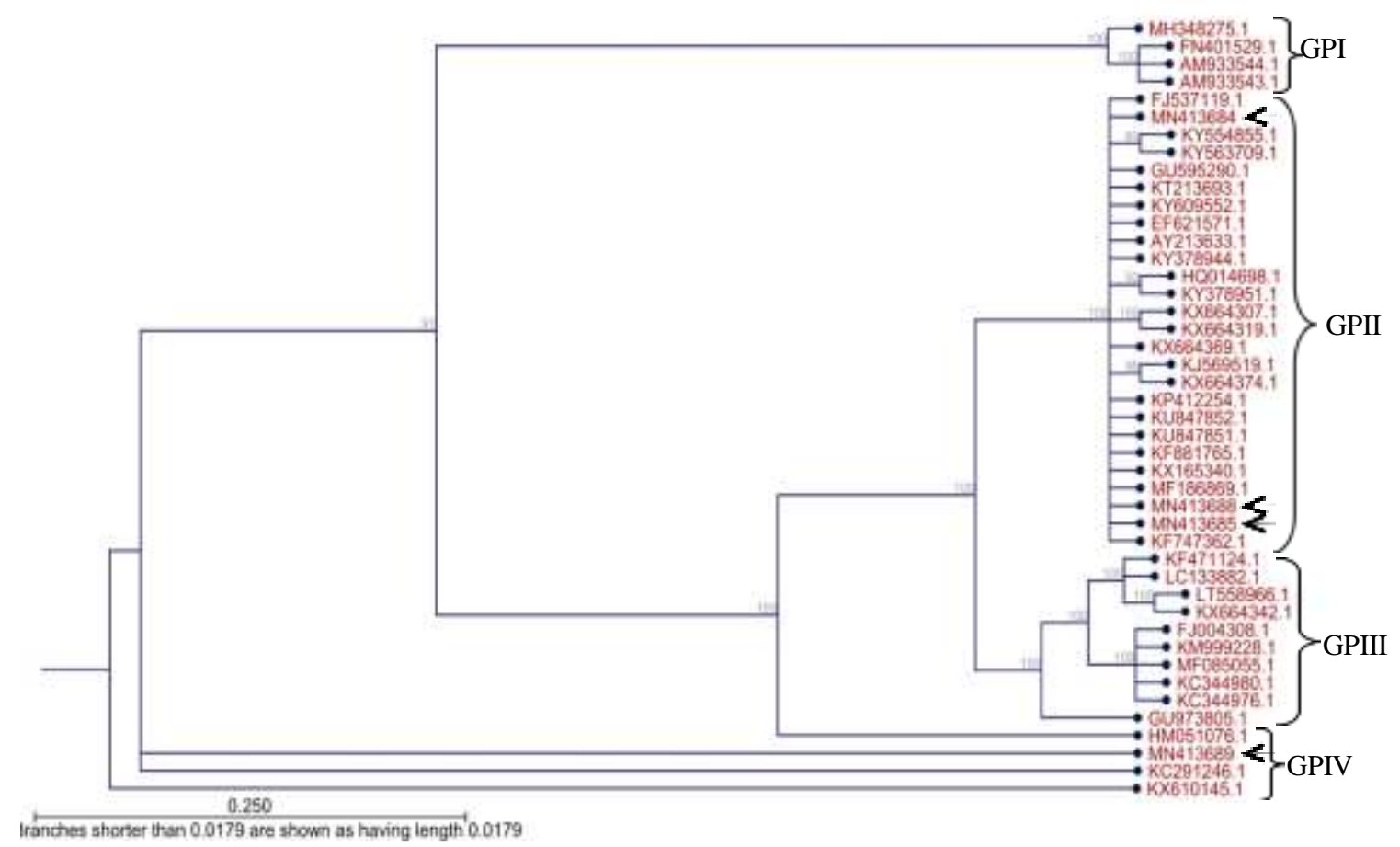

Figure 3. Phylogenetic relationships based on the ITS rDNA regions of the spoilage fungi isolated from soft date fruits. This tree was obtained by neighbor-joining (NJ). The numbers at the branch nodes represent the bootstrap values.

Abass (2013) and Al Hazzani et al. (2014), while AlJasser (2010) found these fungi on date palm fruits.

In this study, the fungal incidence in certain types of dates are indicated as follows: $39.7 \%$ A. niger, $24 \% T$. minioluteus, $14.2 \% \quad A$. tubingensis and $22.1 \% R$. stolonifer found in Sukkary dates. While, the incidence of $A$. niger, A. tubingensis, T. minioluteus and $R$. stolonifer were $0,54.5,9.2$ and $36.3 \%$ in Ajwa, respectively. Surprisingly, the incidence of $A$. niger and $A$. tubingensis in Shalabi Madinah and in Barni were 34, 66, 37.5 and $62.5 \%$, respectively, and were free from $T$. minioluteus and $R$. stolonifer. Only Sogea dates were contaminated mostly with Aspergillus niger (100\%). These results concur with those reported by Colman et al. (2012) which collected about 360 date fruits from Maiduguri metropolis markets for the detection of the presence of 327 $(90.83 \%)$ fungal species and noted that the highest percentage was $A$. niger $(39.17 \%)$, followed by other
Aspergillus spp.

Our results have shown that soft date fruits are much more prone to contamination by Aspergillus spp. than other fungal species. The results were similar to those reported in Egypt by Abdel-Sater and Saber (1999) which found that Aspergillus was the predominant genus isolated from date samples, Aspergillus niger were the most isolated Aspergillus spp. Rhizopus stolonifer was $25 \%$ of the samples which considered the second most common fungus isolated from dried fruits in Yemen (Saeed et al., 2004). Other results recorded in Iraq by Hameed and Abass (2006), Abass et al. (2007) and Abass (2013) showed about $27 \%$ A. niger, which was the most predominant species as contaminants of the different dates. Moreover, Al Hazzani et al. (2014) found that the variety Sukhari was found to be the most contaminated fruit with fungi and $A$. niger was the most predominant fungi present in date fruits collected from the 


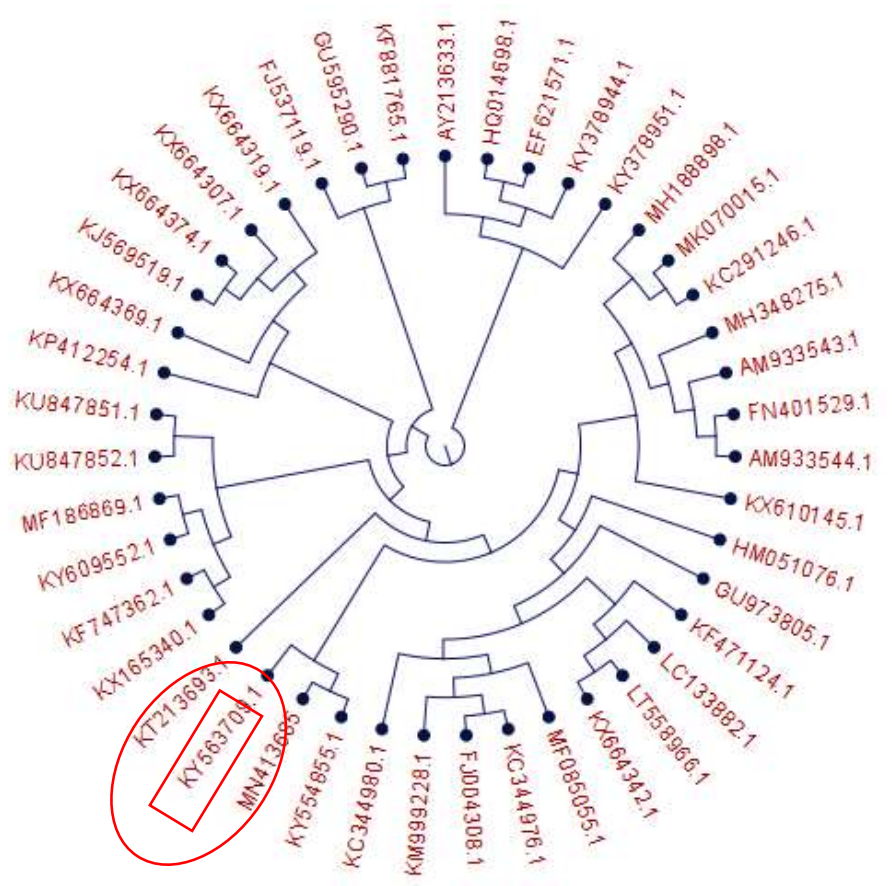

Figure 4. Phylogenetic tree of accession number MN413685 (Aspergillus niger) isolate MJU-2 internal transcribed spacer 1, partial sequence; 5.8S ribosomal RNA gene with other fungal sp.18S ribosomal RNA gene.

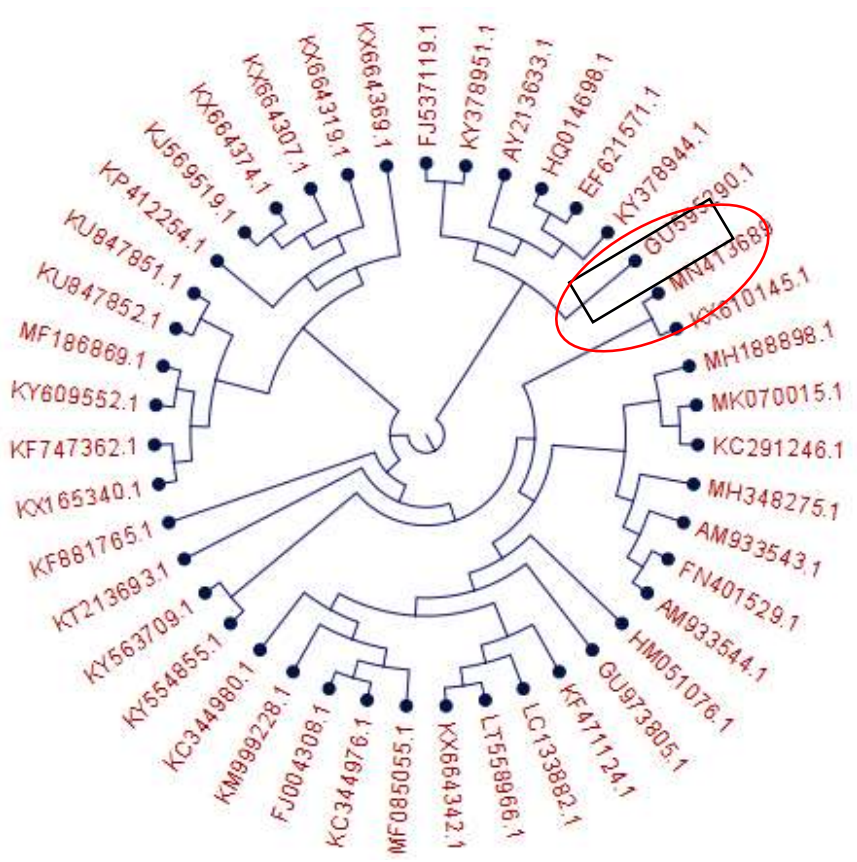

Figure 6. Phylogenetic tree of accession number MN413689 (Talaromyces minioluteus) isolate MJU-6 internal transcribed spacer 1, partial sequence; 5.8S ribosomal RNA gene with other fungal sp.18S ribosomal RNA gene.

open markets of Riyadh, Medina and Kharj, Saudi Arabia.

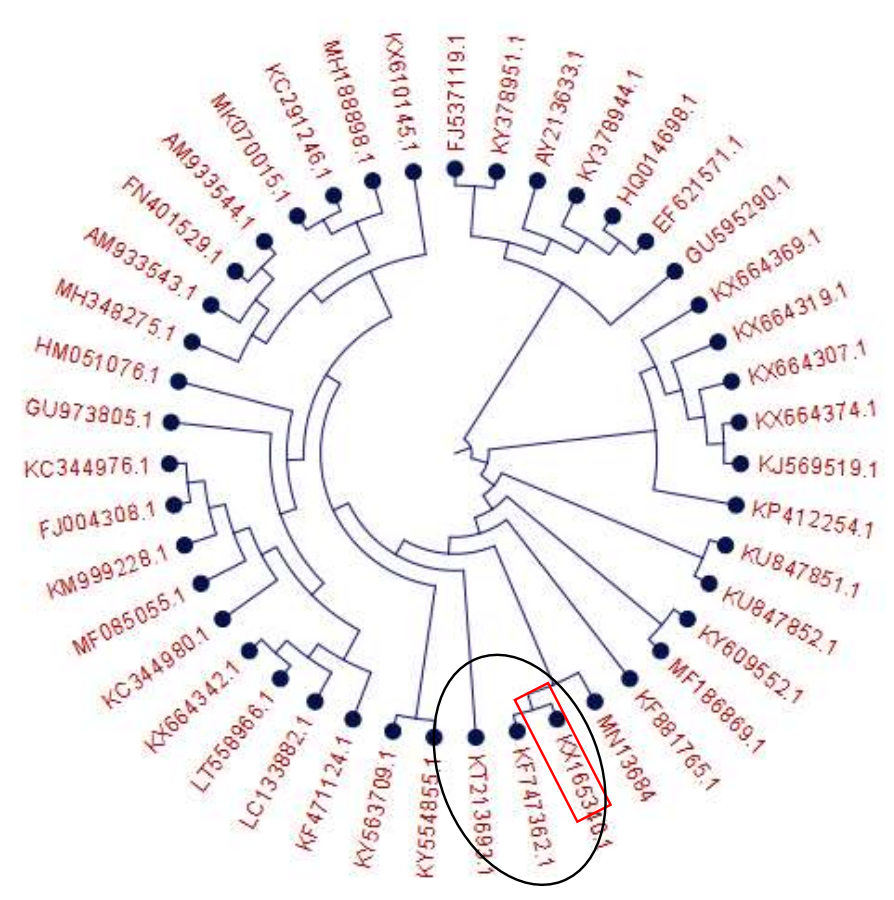

Figure 5. Phylogenetic tree of accession number MN413684 (Aspergillus tubingensis) isolate MJU-1 internal transcribed spacer 1 , partial sequence; $5.8 \mathrm{~S}$ ribosomal RNA gene with other fungal sp.18S ribosomal RNA gene.

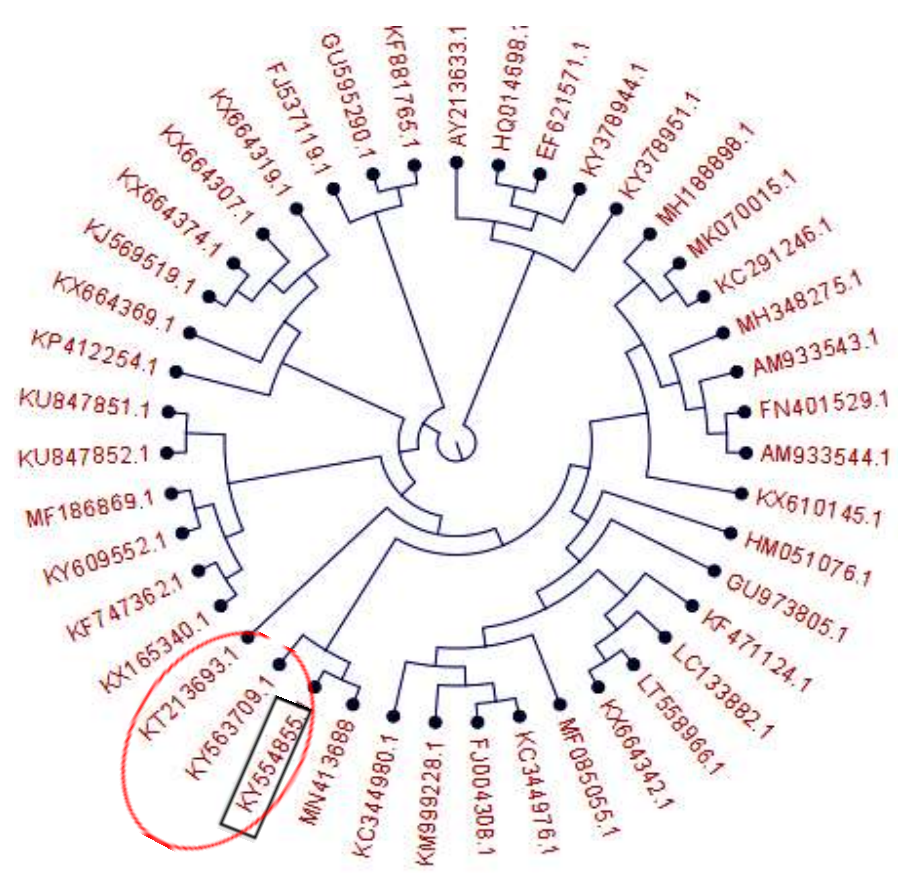

Figure 7. Phylogenetic tree of accession number MN413688 (Rhizopus stolonifer) isolate MJU-5 internal transcribed spacer 1 , partial sequence; $5.8 \mathrm{~S}$ ribosomal RNA gene with other Fungal sp.18S ribosomal RNA gene.

On other hand, the results of the current study disagreed 
Table 2. Information and identification for ITS rDNA sequences of the species of spoilage fungi isolated from sweet date fruits.

\begin{tabular}{|c|c|c|c|c|c|c|}
\hline \multirow[b]{2}{*}{ No. } & \multirow[b]{2}{*}{ Isolate ID } & \multirow[b]{2}{*}{$\begin{array}{l}\text { Species and strain accession } \\
\text { number }\end{array}$} & \multicolumn{3}{|l|}{ ITS rDNA } & \multirow[b]{2}{*}{ Reference } \\
\hline & & & Identification & $\begin{array}{l}\text { Identity } \\
(\%)\end{array}$ & $\begin{array}{l}\text { Length } \\
\text { (bp) }\end{array}$ & \\
\hline 1. & MJU-1 & MN413684 & Aspergillus tubingensis & $99 \%$ & 579 & This study \\
\hline 2. & MJU-2 & MN413685 & Aspergillus niger & $99 \%$ & 589 & This study \\
\hline 3. & MJU-5 & MN413688 & Rhizopus stolonifer & $99 \%$ & 584 & This study \\
\hline 4. & MJU-6 & MN413689 & Talaromyces minioluteus & $99 \%$ & 536 & This study \\
\hline 5. & & $\begin{array}{l}\text { Aspergillus tubingensis strain } \\
\text { HKAS } 93727\end{array}$ & Aspergillus tubingensis & $99 \%$ & 592 & GenBank: KX165340 \\
\hline 6. & & $\begin{array}{l}\text { Aspergillus niger strain SCAU-F- } \\
99\end{array}$ & Aspergillus niger & $99 \%$ & 597 & GenBank: KF881765 \\
\hline 7. & $129 \mathrm{~B}$ & $\begin{array}{l}\text { Aspergillus niger } \\
\text { isolate } 129 \mathrm{~B}\end{array}$ & Aspergillus niger & $99 \%$ & 590 & GenBank: KU847851 \\
\hline 8. & & $\begin{array}{l}\text { Aspergillus tubingensis strain } \\
\text { DGY03 }\end{array}$ & Aspergillus tubingensis & $99 \%$ & 591 & GenBank: MF186869 \\
\hline 9. & FIS17 & $\begin{array}{l}\text { Aspergillus niger isolate isolate } \\
\text { FIS17 }\end{array}$ & Aspergillus niger & $99 \%$ & 594 & GenBank: KY378951 \\
\hline 10. & F03-05 & $\begin{array}{l}\text { Aspergillus tubingensis isolate } \\
\text { F03-05 }\end{array}$ & Aspergillus tubingensis & $99 \%$ & 597 & GenBank: KX664319 \\
\hline 11. & F01-01 & $\begin{array}{l}\text { Aspergillus tubingensis isolate } \\
\text { F01-01 }\end{array}$ & Aspergillus tubingensis & $99 \%$ & 599 & GenBank: KX664307 \\
\hline 12. & $\mathrm{UACH}-198$ & $\begin{array}{l}\text { Rhizopus stolonifer isolate } \\
\text { UACH-198 }\end{array}$ & Rhizopus stolonifer & $99 \%$ & 587 & GenBank: KY563709 \\
\hline 13. & $\mathrm{UACH}-146$ & $\begin{array}{l}\text { Aspergillus niger } \\
\text { isolate UACH-146 }\end{array}$ & Aspergillus niger & $99 \%$ & 587 & GenBank: KY554855 \\
\hline 14. & ZJ13 & $\begin{array}{l}\text { Aspergillus tubingensis isolate } \\
\text { ZJ13 }\end{array}$ & Aspergillus tubingensis & $99 \%$ & 595 & GenBank: KP412254 \\
\hline 15. & FIS2 & $\begin{array}{l}\text { Aspergillus tubingensis isolate } \\
\text { FIS2 }\end{array}$ & Aspergillus tubingensis & $99 \%$ & 594 & GenBank: KY378944 \\
\hline 16. & 132 & $\begin{array}{l}\text { Aspergillus tubingensis isolate } \\
132\end{array}$ & Aspergillus tubingensis & $99 \%$ & 590 & GenBank: KU847852 \\
\hline 17. & TFR29 & $\begin{array}{l}\text { Aspergillus tubingensis isolate } \\
\text { TFR29 }\end{array}$ & Aspergillus tubingensis & $99 \%$ & 598 & GenBank: KX664374 \\
\hline 18. & F33-01 & $\begin{array}{l}\text { Aspergillus tubingensis isolate } \\
\text { F33-01 }\end{array}$ & Aspergillus tubingensis & $99 \%$ & 594 & GenBank: KT213693 \\
\hline 19. & & $\begin{array}{l}\text { Aspergillus tubingensis strain } \\
\text { LYF12 }\end{array}$ & Aspergillus tubingensis & $99 \%$ & 594 & GenBank: KJ569519 \\
\hline 20. & & Aspergillus niger strain CICR3 & Aspergillus niger & $99 \%$ & 597 & GenBank: KF747362 \\
\hline 21. & & $\begin{array}{l}\text { Aspergillus tubingensis } \\
\text { strain } 3.4342\end{array}$ & Aspergillus tubingensis & $99 \%$ & 582 & GenBank: EF621571 \\
\hline 22. & & $\begin{array}{l}\text { Aspergillus niger } \\
\text { strain WM10.76 }\end{array}$ & Aspergillus niger & $99 \%$ & 590 & GenBank: HQ014698 \\
\hline 23. & & $\begin{array}{l}\text { Aspergillus niger } \\
\text { strain EN2 }\end{array}$ & Aspergillus niger & $99 \%$ & 583 & GenBank: KY609552 \\
\hline 24. & & $\begin{array}{l}\text { Aspergillus tubingensis strain } \\
\text { GX1-5E }\end{array}$ & Aspergillus tubingensis & $99 \%$ & 584 & GenBank: GU595290 \\
\hline 25. & & $\begin{array}{l}\text { Aspergillus niger } \\
\text { strain UWFP } 515\end{array}$ & Aspergillus niger & $99 \%$ & 584 & GenBank: AY213633 \\
\hline 26. & $\begin{array}{l}\text { South- } \\
\text { west0056 }\end{array}$ & $\begin{array}{l}\text { Aspergillus tubingensis isolate } \\
\text { South-west } 0056\end{array}$ & Aspergillus tubingensis & $99 \%$ & 530 & GenBank: FJ537119 \\
\hline 27. & F28-03 & $\begin{array}{l}\text { Aspergillus tubingensis isolate } \\
\text { F28-03 }\end{array}$ & Aspergillus tubingensis & $99 \%$ & 602 & GenBank: KX664369 \\
\hline 28. & PILE 14-5 & $\begin{array}{l}\text { Talaromyces minioluteus isolate } \\
\text { PILE 14-5 }\end{array}$ & Talaromyces minioluteus & $99 \%$ & 545 & GenBank: KF471124 \\
\hline
\end{tabular}


Table 2. Information and identification for ITS rDNA sequences of the species of spoilage fungi isolated from sweet date fruits.

\begin{tabular}{|c|c|c|c|c|c|c|}
\hline 29. & F21-01 & $\begin{array}{l}\text { Talaromyces diversus isolate } \\
\text { F21-01 }\end{array}$ & Talaromyces diversus & $97 \%$ & 596 & GenBank: KX664342 \\
\hline 30. & & $\begin{array}{l}\text { Talaromyces minioluteus strain } \\
\text { E93 }\end{array}$ & Talaromyces minioluteus & $99 \%$ & 556 & GenBank: KX610145 \\
\hline 31. & & $\begin{array}{l}\text { Talaromyces sp } \\
\text { DI16-144 }\end{array}$ & Talaromyces sp. & $97 \%$ & 592 & GenBank: LT558966 \\
\hline 32. & & $\begin{array}{l}\text { Talaromyces sp } \\
\text { JCM } 28523\end{array}$ & Talaromyces sp. & $97 \%$ & 575 & GenBank: LC133882 \\
\hline 33. & & $\begin{array}{ll}\text { Talaromyces } & \text { purpureogenus } \\
\text { strain CFRM02 } & \end{array}$ & $\begin{array}{l}\text { Talaromyces } \\
\text { purpureogenus }\end{array}$ & $94 \%$ & 523 & GenBank: MF085055 \\
\hline 34. & LN2R560 & $\begin{array}{ll}\text { Talaromyces } & \text { purpureogenus } \\
\text { isolate LN2R560 }\end{array}$ & $\begin{array}{l}\text { Talaromyces } \\
\text { purpureogenus }\end{array}$ & $94 \%$ & 513 & KM999228 \\
\hline 35. & & $\begin{array}{l}\text { Talaromyces purpureogenus } \\
\text { strain ATHUM } 5090\end{array}$ & $\begin{array}{l}\text { Talaromyces } \\
\text { purpureogenus }\end{array}$ & $94 \%$ & 522 & FJ004308 \\
\hline 36. & & $\begin{array}{ll}\text { Talaromyces } & \text { purpurogenus } \\
\text { strain A3S3-40 } & \end{array}$ & $\begin{array}{l}\text { Talaromyces } \\
\text { purpurogenus }\end{array}$ & $94 \%$ & 556 & KC344980 \\
\hline 37. & & $\begin{array}{l}\text { Talaromyces } \\
\text { strain A4S1 }\end{array}$ & $\begin{array}{l}\text { Talaromyces } \\
\text { purpurogenus }\end{array}$ & $94 \%$ & 513 & KC344976 \\
\hline 38. & & Aspergillus niger strain TFR-4 & Aspergillus niger & $94 \%$ & 513 & GU973805 \\
\hline 39. & & Rhizopus stolonifer & Rhizopus stolonifer & $99 \%$ & 590 & KC291246 \\
\hline 40. & wxm171 & $\begin{array}{l}\text { Rhizopus stolonifer isolate } \\
\text { wxm171 }\end{array}$ & Rhizopus stolonifer & $92 \%$ & 243 & HM051076 \\
\hline 41. & RWP-47 & $\begin{array}{l}\text { Rhizopus stolonifer isolate RWP- } \\
47\end{array}$ & Rhizopus stolonifer & $87 \%$ & 145 & MH348275 \\
\hline 42. & & $\begin{array}{l}\text { Rhizopus stolonifer } \\
\text { strain TUR5 }\end{array}$ & Rhizopus stolonifer & $87 \%$ & 145 & AM933544 \\
\hline 43. & TUR8 & $\begin{array}{l}\text { Rhizopus stolonifer } \\
\text { isolate TUR8 }\end{array}$ & Rhizopus stolonifer & $87 \%$ & 145 & FN401529 \\
\hline 44. & & $\begin{array}{l}\text { Rhizopus stolonifer } \\
\text { strain TUR1 }\end{array}$ & Rhizopus stolonifer & $87 \%$ & 145 & AM933543 \\
\hline
\end{tabular}

with the results of Ibrahim and Rahma (2009), who found that Rhizopus spp. was the dominant isolate; however, Deeb et al. (2006) failed to isolate any of the mentioned fungus spp. These differences could be attributed to the variation in geographical location.

$A$. niger is a filamentous ascomycete fungus that is ubiquitous in different environments and the most common member of the microbial communities found in soil, air and many other environments (Samson et al., 2002; Al-Mayahi et al., 2010). Hence, its saprophytic activity with a wide range of oxidative and hydrolytic enzymes enables this fungus to grow wherever there is a suitable source of food and moisture (Schuster et al., 2002). These black Aspergilli can produce Ochratoxin A (OTA) in various food commodities (Schuster et al., 2002). Ochratoxin is identified as a renal carcinogen to particular animal species (Kuiper-Goodman and Scott, 1989) and can cause nephrotoxic, teratogenic and immunosuppressive effects in multiple animal species (Kuiper-Goodman and Scott, 1989; O'Brien and Dietrich, 2005).

Date fruits sold in shops or market places were neither covered nor protected in any way from dust or atmospheric contamination, and when consumed without any form of washing or clearing could enhance mycotic infection.

In this study, the fungal isolates were first identified at the level of the genus by morphological examination, depending on the colors of the colony formed on both sides, on the top and on the back of the fungal cultures. The morphological examination and identification of fungi are useful for the identification of isolates up to the family or genus level (Wang et al., 2016). However, this identification is not adequate to identify the isolated fungi up to the species level (Lutzoni et al., 2004).

The application of molecular identification is quick, adequate, reproducible and highly specific, in contrast to morphological and biochemical tests for the diagnosis of fungi in the laboratory (Liu et al., 2000). The molecular identification of isolated fungi was carried out by DNA amplification using the ITS region sequencing. The ITS rDNA sequences were compared to those in the databases using NCBI-BLAST. The sequence of ITS rDNA region is known to be one of the key tools to 
which added great benefits to the process of distinguishing between similar species of fungi in

Al-Mutarrafi et al.

identify fungal species from environmental sources (Anderson and Parkin, 2007) and was therefore used extensively to enhance the classical identifications. Our results of PCR amplification was conducted using internal transcribed spacer (ITS) PCR products amplified from the predominant fungi using ITS1 and ITS4 primers. The results showed that the PCR product sizes of the ITS rDNA regions were of variable lengths, from 536 to 596 bp. The ITS rDNA PCR product obtained from $A$. niger isolate was (596 bp), whereas it was $536 \mathrm{bp}$ from $T$. minioluteus isolate. The obtained results were in agreement with that reported by Abass (2013) who molecularly characterized the most abundant fungal contaminants of date palm in which, the Aspergillus species were found to be the most frequently isolated species, followed by the species of Alternaria and Penicillium.

Four fungal species were identified using DNA sequencing with an identity range between 87 and 99\%. The DNA sequence and phylogenetic analysis indicated that the sequence analysis of the ITS regions showed significant alignments for accession number MN413684, MN413685, MN413688 and MN413689 respectively, with other 44 reference sequences of related species obtained from Gen-Bank. Isolates within each species were clustered together and distinctly separated from the others. The generated dendogram shows that the studied isolates were clustered in three groups. The first group (I) includes MN413689 isolate MJU-6, the second group include the accession number MN413684 isolate MJU-1. The third group includes two accession numbers MN413685 isolate MJU-2 and MN413688 isolate MJU-5. The same clustering method used in the current study were also reported by Awa and Oguntade (2015) who conducted a quick molecular test based on the amplification of fragments of the internal transcribed spacer (ITS1) region to distinguish Colletotrichum isolates from other pathogenic fungi. The analysis of the nucleotide sequences of the ribosomal DNA (rDNA) fragment showed sufficient variability to clearly classify the 7 fungal species isolated from symptomatic mango fruits into Colletotrichum gloeosporioides, Fusarium verticillioides and Lasiodiplodia theobromae. Chromatogram produced from their rDNA data confirmed the identities of the fungal isolates. Chul-Kwon et al. (2018) identified 18 spoilage fungi isolated from mulberry fruits and molecularly characterized based on the comparisons of the ITS rDNA sequences.

\section{CONCLUSION}

The isolation and identification of filamentous fungi from soft dates in Saudi Arabi showed existence of some economically-important fungi. The study specifically employed the molecular technique in fungal identification comparison with the traditional techniques.

The research also discusses date fruits sold in open areas which are not shielded from contamination and may be consumed without hygiene, might increase the risk of mycotic infection.

\section{ACKNOWLEDGEMENTS}

We would like to pass our sincere gratitude to the University of Jeddah for the technical support to carry out this study.

\section{REFERENCES}

Abass MH, Al-Abadi UAM, AlKaby AMS, 2007. The efficiency of Henna leaves extracts and some fungicides to reduce the fungal contamination of date palm Phoenix dactylifera $\mathrm{L}$ tissue culture Iraqi J Biotech, 62: 1-40.

Abass $\mathrm{MH}$, 2013. Microbial contaminants of date palm Phoenix dactylifera $\mathrm{L}$ in Iraqi tissue culture laboratories. Emir J Food Agric, 25(11):875-882.

Abdel-Sater MA, Saber SM, 1999. Mycoflora and Mycotoxins of some Egyptian dried fruits. Bull Fac Sci Assiut Univ, 28:91-107.

Al Hazzani A, Al-Rizwana H, Moubayed NMS, Alshatwi AA, Munshi A, Elgaaly G, 2014. Postharvest fruit spoilage bacteria and fungi associated with date palm Phoenix dactylifera $L$ from Saudi Arabia. Afr J Microbiol Res, 8(11): 1228-1236.

Al-Bulushi IM, Bani-Uraba MS, Guizani NS, Al-Khusaibi MK, and AlSadi AM, 2017. Illumina MiSeq sequencing analysis of fungal diversity in stored dates. BMC Microbiol, 17, 72.

Al-Farsi MA, Lee CY, 2008. Optimization of phenolics and dietary fibre extraction from date seeds Food Chemistry, 108(3): 977-985.

Al-Jasser MS, 2010. Effect of storage temperatures on microbial load of some date palm fruits sold in Saudi Arabia market. African Journal of Food Science 4(6):359-363.

Al-Mayahi AM, Ahmed AN, AlKhalifa AA, 2010. Isolation and identification of associated fungi with the micropropagation of five different date palm cultivars and the effect of Benlate fungicides in their control. Basra J Date Palm Res, 92: 79-97.

Al-Shahib W, Marshall R, 2003. The fruit of the date palm: Its possible use as the best food for the future. Int J Food Sci Nutrit, 544: 247 259.

Anderson IC, Parkin PI, 2007. Detection of active soil fungi by RTPCR amplification of precursor rRNA molecules. J Microbiol Methods, 68: 248-253.

Atia MM, El-Mahmodi AM, El-Shili M, 2009. Fungi Associated with Some Stored Date Palm Fruits in Libya. The 3rd National Conference on Basic Science Under the Title: Basic Sciences are the Main Source of Creativity Gharian Libya from. 25 - 27.

Awa OC, Oguntade O, 2015. Molecular Identification of fungal species associated with mango anthracnose in Southwest Nigeria. J Agric Environ Sci, 42: 99-103.

Chul-Kwon O, Ju WT, Bok Kim H, Sung GB, Kim YS, 2018. Isolation and identification of postharvest spoilage fungi from mulberry fruit in Korea. Korean J Environ Agric, 373: 221-228.

Colman S, Spencer THI, Ghamba PE, Colman E, 2012. Isolation and identification of fungal species from dried date palm Phoenix dactylifera fruits sold in Maiduguri metropolis. Afr $\mathrm{J}$ Biotechnol, 11(57): 12063-12066.

Deeb HM, Lashin SM, Arab YA, 2006. Distribution and pathogenesis of date palm fungi in Egypt. ISHS Acta Horticultural, 736: 22-46.

Elhindi KM, Sharaf El-Din A, Elgorban AM, 2017. The impact of arbuscular mycorrhizal fungi in mitigating salt-induced adverse 
effects in sweet basil Ocimum basilicum L. Saud J Biol Sci, 24(1): 170-179.

FAO, 2008. "Date Palm" http://faostatefaoorg/ site/340/default.

Gherbawy YA, Elhariry HM, Bahobial AAS, 2012. Mycobiota and

mycotoxins (aflatoxins and ochratoxin) associated with some Saudi date palm fruits. Foodborne Pathog Dis, 9(6): 561-567

Hameed MA, Abass MH, 2006. Study of cytological changes associated with contaminated date palm Phoenix dactylifera $\mathrm{L}$ tissue cultures with fungi. Basra Res J, 32: 127.

Hashem A, 2009. Date palm fruit spoilage and seed-born fruit of Saudi Arabia. Res J Microbiol, 4:208-213.

Hasnaoui A, Elhoumaizi MA, Asehraou A, Hakkou A, 2010. Chemical composition and microbial quality of main varieties of dates grown in Figuig oasis of Morocco. Int J Agric Biol, 12: 311-314.

Ibrahim S, Rahma MA, 2009. Isolation and identification of fungi associated with date palm fruits Phoenix dactylifera sold at Beyaro University, Kano, Nigeria. Bayero. J Pure Appl Sci, 2: 127-130.

lamanaka $\mathrm{BT}$, Taniwaki $\mathrm{MH}$, Menezes $\mathrm{HC}$, Vicente $\mathrm{E}$, Fungaro MHP, 2005. Incidence of toxigenic fungi and ochratoxin $A$ in dried fruits sold in Brazil. Food Additives and Contaminants, 22: 1258-1263.

Jha $D, 1995$. Laboratory manual on seed pathology. Villas Publishing House PVT Ltd. pp. $13-30$.

Jukes TH, Cantor CR, 1969. Evolution of protein molecules Munro HN Ed Mammalian protein metabolism III New York: Academic Press, 121-132.

Kader AA, Hussein AM, 2009. Harvesting and postharvest handling of dates, ICARDA, Aleppo, Syria, $15 \mathrm{pp}$.

Liu D, Coloe S, Baird R and Pedersen J. 2000. Application of PCR to the identification of dermatophyte fungi. J Med Microbiol, 49: 493497.

Lutzoni F, Kauff F, Cox CJ, Mc Laughlin D, Celio G, Dentinger B, Padamsee M, Hibbett D, James TY, Baloch E, Grube M, Reeb V, Hofstetter V, Schoch C, Arnold AE, Miadlikowska J, Spatafora J, Johnson D, Hambleton S, Crockett M, Shoemaker R, Sung GH, Lücking R, Lumbsch T, O'Donnell K, Binder M, Diederich P, Ertz D, Gueidan C, Hansen K, Harris RC, Hosaka K, Lim YW, Matheny B, Nishida H, Pfister D, Rogers J, Rossman A, Schmitt I, Sipman H, Stone J, Sugiyama J, Yahr R, Vilgalys R, 2004. Assembling the fungal tree of life: progress, classification and evolution of the subcellular traits. Am J Bot, 91: 1446-1480.

Kuiper-Goodman T, Scott PM, 1989. Risk assessment of the mycotoxin ochratoxin A. Biomed Environ Sci, 2: 179-248.

Mirza MB, Sayed FQ, Khan F, Elkady Al, Al-Attar AM, Hakeem KR, 2019. Ajwa Dates: A Highly Nutritive Fruit with the Impending Therapeutic Application Chapter in Plant and Human Health Volume 3: Pharmacology and Therapeutic Uses edited by Münir Ahmet Öztürk Khalid Rehman Hakeem. 211-229.

O'Brien E, Dietrich DR, 2005. Ochratoxin A: The continuing enigma. Crit Rev Toxicol, 35: 33-60.
Raja HA, Miller AN, Pearce CJ, Oberlies NH, 2017. Fungal identification using molecular tools: A primer for the natural products research community. J Nat Prod, 80(3): 756-770.

Saeed M, Alghalibi S, Abdul-Rahman MS, 2004. Mycoflora and mycotoxin contamination of some dried fruits in Yemen Republic. Ass Univ Bull Environ Res, 72: 19-27.

Samson RA, Houbraken J, Summerbell RC, Flannigan B, Miller JD, 2002. Common and important species of fungi and actinomycetes in indoor environments In: B Flannigan, RA Samson and JD Miller Eds, 287-292.

Schuster E, Dunn-Coleman N, Frisvad JC, Van Dijck PW, 2002. On the safety of Aspergillus niger - A review. Appl Microbiol Biotech, 59(4-5): 426-435.

Singh D, Sharma RR, 2007. Postharvest diseases of fruit and vegetables and their management. In: Prasad, D Ed., Sustainable Pest Management Daya Publishing House: New Delhi, India.

Shenasi M, Kofi A, Candlish A, 2002. Microflora of date fruits and production of aflatoxins at various stage of maturation. Int $\mathrm{J}$ Food Microbiol, 79: 113-119.

Tamura K, Stecher G, Peterson D, Filipski A, Kumar S, 2013. MEGA6: Molecular Evolutionary Genetics Analysis Version 6.0. Mol Biol Evol, 30(12): 2725-2729.

Wang Z, Nilsson RH, James TY, Dai Yand Townsend JP, 2016. Future Perspectives and Challenges of Fungal Systematics in the Age of Big Data. Biology of Microfungi. Springer, pp. 25-46.

Citation: Al-Mutarrafi M, Elsharawy NT, Al-Ayafi A, Almatrafi A Abdelkader H, 2019. Molecular identification of some fungi associated with soft dates (Phoenix Dactylifera L.) in Saudi Arabia. Adv Med Plant Res, 7(4): 97-106. 